\title{
Photosynthetic Response of Two Rice Field Cyanobacteria to Pesticides
}

\author{
Binata Nayak, Shantanu Bhattacharyya and Jayanta K. Sahu
}

Additional information is available at the end of the chapter

http://dx.doi.org/10.5772/46232

\section{Introduction}

It was 2.4 billion ( $\mathrm{Ga}$ ) years ago that oxygen accumulated atmosphere began in our planet and cyanobacteria (earlier known as Bluegreen algae) are inhabitant of almost 3.5 billions years ago. This oxygenic atmosphere lead to the evolution of life on the earth. The exponential growth rate and long life span of human beings now a days creating a population bomb which is going to affect the environmental stability. In present day scenario of population explosion, it is essential to increase food production to meet the food demands and to maintain the socioeconomic status of the people in all the developing countries including India. In the year 2050, India will reach to the highest population (1.22 billion in 2012), within this globe total population of world will be approx 9.1 billion in 2050 (Carvalho, 2006). The immediate response to increase food production in limited agricultural land areas is possible by intensive use of agrochemicals. Agrochemicals include two large groups of compounds: chemical fertilizers and pesticides. The use of chemical fertilizers tremendously increased worldwide since 1960s and was largely responsible for the "green revolution", i.e. the massive increase in production obtained from the same surface of land with the help of mineral fertilizers and intensive irrigation. The revolution was assisted also with the introduction of more productive varieties of crops.

The use of pesticides, including insecticides, fungicides, herbicides, rodenticides, etc., to protect crops from pests, allowed to significantly reduce the losses and to improve the yield of crops. The application of different agrochemicals is region specific. In the tropical regions, where insect pests and plant diseases are more frequent, pesticides are generally applied in massive amounts, both in small farms as well as in cash crop. It has been reported that especially the organochlorine and organophosphorus pesticide residues, are found in soils, atmosphere and in the aquatic environment in relatively high concentrations (Carvalho et al., 1997). Pesticides are poisons, intentionally dispersed in the environment to control pests but 
they also act upon other species causing serious side effects on non-target species and destabilise the ecosystem. Cyanobacteria the natural nitrogen engineer of the soil are also adversely affected by indiscriminate use of pesticides.

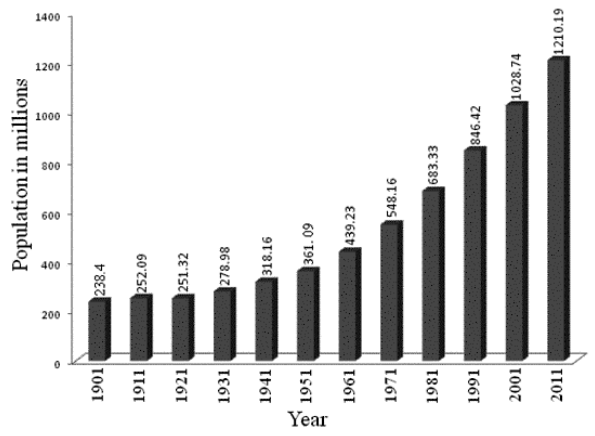

Figure 1. Increasing rate of population

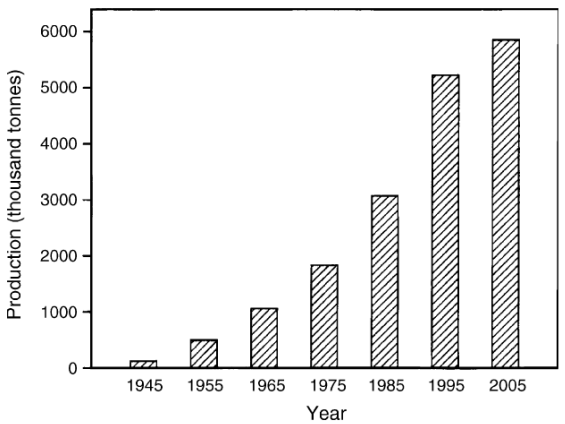

Figure 2. World production of formulated pesticides. Data for year 2005 is estimated (sourse Agrochemical service,2000)

\begin{tabular}{|c|c|c|c|c|c|c|c|}
\hline$\underset{\text { Z゙ }}{\stackrel{\Xi}{Z}}$ & 苞 & 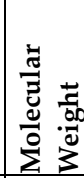 & 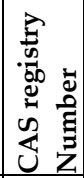 & 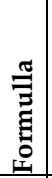 & 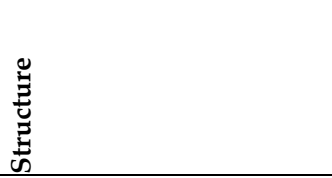 & 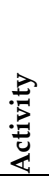 & 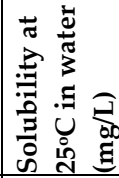 \\
\hline 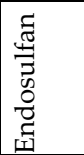 & $\begin{array}{l}\text { 6,7,8,9,10,10-hexachloro- } \\
1,5,5 a, 6,9,9 a-h e x a h y d r o-6,9- \\
\text { methano-2,4,3- } \\
\text { benzadioxathiepin 3-oxide }\end{array}$ & 406.96 & \begin{tabular}{|l|}
$115-$ \\
$29-7$
\end{tabular} & 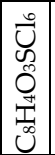 & & 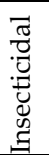 & $36 \%$ \\
\hline 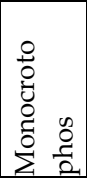 & $\begin{array}{l}\text { dimethyl (E)-1-methyl-2- } \\
\text { (methylcarbamoyl)vinyl } \\
\text { phosphate }\end{array}$ & 223.2 & $\begin{array}{l}2157- \\
98-4\end{array}$ & 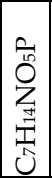 & 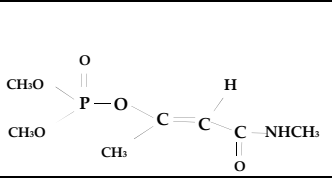 & 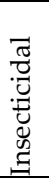 & $35 \%$ \\
\hline
\end{tabular}

Table 1. Physicochemical characteristics of Monocrotophos and Endosulfan 
Cyanobacteria are the most diversified ecologically, most successful and evolutionarily most important group of photosynthetic prokaryotes (Peschek et al., 1994) and maintain the homeostasis of nitrogen budget of the rice agroecosystem by photobiological nitrogen fixation in a specialized cell called heterocyst (Fay et al., 1968) at almost zero cost (Mishra \& Pabbi 2004). Diversity and evolutionary information of cyanobacteria are available in the internet and for images one can search for "cyanobacteria, images" using Google. Most paddy soils have a natural population of cyanobacteria as they grow and multiply at the simple expense of water, light and air (Fay 1983). Soil nitrogen is the main source of nitrogen for crop growth and rice plant consume 50\% of soil nitrogen (Fernandez-valiante et al., 2000). Several reports are available on the adverse effect of agrochemicals on cyanobacteria (Marsac \& Houmard, 1993; Das \& Adhikary, 1996; Kapoor \& Arora, 2000a, 2000b; Shikha \& Singh, 2004; Xia, 2005; Kim \& Lee, 2006). Although a lot of work has been done on the effect of pesticide in general, no attempt has been made on the effect of pesticide in locally growing cyanobacteria of Western Odisha, India. Farmers of this region use Monocrotophos and Endosulfan on a large scale in rice fields as both the pesticide have broad spectrum activity and they control the attack of insects; the physicochemical properties of both pesticides are given in Table 1.

BGA biofertilizer are added to rice fields to increase the fertility of soil and to minimize dependence on chemical fertilizer. The aim of the present study was to investigate whether Anabaena sp. and Nostoc sp., the locally isolated rice field cyanobacteria can be recommended to use as biofertilizer by tolerating the deleterious effect of Monocrotophos and Endosulfan. The chapter presents experimental results to illustrate the effects of Monocrotophos and Endosulfan in time and concentration dependent manner on growth, pigments and photosynthesis of these two alga.

\section{Material and methods}

Two species of heterocystous cyanobacteria belonging to genera Anabaena and Nostoc isolated from rice field. Selection of these two genus was based on their relatively better growth rate and wider occurance. Two commercial grade pesticide i.e. Monocrotophos (organophosphate 36\%SL) and Endosulfan (organochlorine 35\%EC) were used in the investigation. Fresh stock solutions of these pesticides were prepared in double distilled water and added to the culture medium to obtain the desired concentration. $\mathrm{pH}$ of all the medium was adjusted to 7.4 prior to sterilisation. Experiments were conducted in $15 \times 150 \mathrm{~mm}$ Borosil test tube containing $10 \mathrm{ml}$ of nitrogen free BG11 medium (Rippka et al., 1979) and by inoculating equal amount of homogenized culture suspension (absorbance of the inoculum of each organism from their exponential growth phase at 760nm was 0.4 always). The medium contained various concentration of Monocrotophos (20,50,100 \&150ppm) and Endosulfan $(1,3,5,10$ and $15 \mathrm{ppm})$,

Growth was measured by light scattering technique by taking the absorbance at 760nm, Chl a pigment of the cyanobacterial cells were extracted with $80 \%$ chilled acetone. Absorbance of the acetone extract was recorded at $660 \mathrm{~nm}$ and the amount of Chl $a$ was determined using extinction coefficient of Mackinney, 1941. 
Algal suspension was homogenized in a glass hand-homogenizer for 5 minutes and then centrifuged at $3500 \mathrm{rpm}$ for 10 minutes. After centriguation, the pellet containing algal cells was resuspended in $50 \mathrm{mM}$ tris- $\mathrm{HCl}$ buffer, $\mathrm{pH} 7.8$ containing $175 \mathrm{mM} \mathrm{NaCl}$. Room temperature $C h l a$ fluorescence emission of algal suspension was measured as per Panda (1999) in a spectrofluorimeter (Hitachi, model, 650-40, Japan). For all scanning, a slit width of $10 \mathrm{~nm}$ was used. The whole cell algal suspension equivalent to $10 \mu \mathrm{g}$ of Chl in a total volume of $3 \mathrm{ml}$ containing $50 \mathrm{mM}$ Tris- $\mathrm{HCl}$ buffer and $175 \mathrm{mM} \mathrm{NaCl}(\mathrm{pH} 7.8)$ was excited at $450 \mathrm{~nm}$ and emission was recorded at $685 \mathrm{~nm}$ for PS II and $735 \mathrm{~nm}$ for PS I emission.

The same algal suspension was also used to measure the excitation emission. During scanning, the emission was monitored at $685 \mathrm{~nm}$ and a slit width of $10 \mathrm{~nm}$ was maintained. Excitation emission was recorded at $439 \mathrm{~nm}, 471 \mathrm{~nm}$ and $485 \mathrm{~nm}$. The excitation energy transfer from Car to Chl was measured by exciting the algal suspension at $475 \mathrm{~nm}$ and 600 $\mathrm{nm}$. The emission was recorded at $685 \mathrm{~nm}$ for PS II and $735 \mathrm{~nm}$ for PS I. Efficiency of the energy transfer was assessed by calculating the ratio of excitation at $475 \mathrm{~nm}$ to $600 \mathrm{~nm}$ as described by Gruszescki et al., 1991.

Fluorescence polarization was measured by exciting the algal suspension at $620 \mathrm{~nm}$ and polarization was recorded at $685 \mathrm{~nm}$. Polarization $(\mathrm{P})$ was calculated as per the following formula of Swain et al., 1990.

$$
P=\frac{I_{v v}-\frac{I_{v h} \times I_{h v}}{I_{h h}}}{I_{v v}+\frac{I_{v h} \times I_{h v}}{I_{h h}}}
$$

where, $\quad I=$ intensity of fluorescence

$\mathrm{v}=$ vertical geometry of the polarizer

$\mathrm{h}=$ horizontal geometry of the analyzer

The 2,6-dichlorophenol indophenol (DCPIP) photoreduction was measured spectrophotometrically as described by Swain et al., 1990 with modification. $3 \mathrm{ml}$ of reaction mixture contained whole cell algal suspension (equivalent to $10 \mu \mathrm{g} \mathrm{Chl}$ ), $50 \mathrm{mM}$ Tris- $\mathrm{HCl}$ buffer ( $\mathrm{pH}$ 7.8 ) and $175 \mathrm{mM} \mathrm{NaCl}$. This reaction mixture was illuminated for 30 seconds with saturating white light $\left(7 \times 10^{4} \mathrm{ergs}^{-2} \mathrm{sec}^{-1}\right)$ coming from a projector lamp. The incident radiation beam was passed through a water filter to minimize infrared radiation. The photoreduction of the dye was measured at $600 \mathrm{~nm}$. The reduction of the dye is expressed as $\mu$ moles DCPIP reduced/mg Chl/hr.

Photosynthetic efficiency of algal suspension in terms of chlorophyll fluorescence was measured at room temperature using a Plant Efficiency Analyzer (Handy PEA, Hansatech Instruments, Norfolk, UK). The Fv/Fm of algal suspension was measured by the Handy PEA after 20 minutes dark-adaption. 


\section{Results and discussion}

The nitrogen-fixing cyanobacteria represent as one of the prominent component of microbial population in wetland soils, especially in rice fields. They significantly contribute to soil fertility as a natural biofertilizer (Kumar \& Kumar, 1998). Some cyanobacterial strains that thrive and grow in rice fields release small quantities of the major fertilizing product ammonia and small polypeptides during active growth whereas most of the other fixed products become available mainly through autolysis and decomposition (Hammouda, 1999). Therefore, cyanobacteria are considered as a vital component of the rice agroecosystem. However, excessive use of pesticides has a detrimental effect on the growth of these beneficial microorganisms, soil fertility and ultimately on the crop productivity. The effect of pesticides on the population of nitrogen fixing organisms varies with characteristics of the species and chemical nature of the pesticide.

\subsection{Changes in the growth pattern}

Growth response of two different species of heterocystous cyanobacteria namely Anabaena sp. and Nostoc sp. to different concentrations of insecticide Monocrotophos is shown in Fig.3. Experiments showed that Anabaena sp. tolerated up to $100 \mathrm{ppm}$ whereas Nostoc sp. tolerated upto $150 \mathrm{ppm}$ of the insecticide where as for Endosulfan its limit was 5ppm \& $15 \mathrm{ppm}$ respectively. Growth curves indicate that both the algae showed lag phase up to 3rd day of incubation followed by rapid growth up to 12th day in case of control and treated (20 ppm for Anabaena sp. and $50 \mathrm{ppm}$ for Nostoc sp.) samples. The present study of growth pattern of Anabaena sp. and Nostoc sp suggest that the tolerance capacity of Nostoc is more compared to Anabaena for both the pesticides. Both the alga also tolerate higher doses of pesticides Monocrotophos compared to Endosulfan. Endosulfan has more inhibitory effect on growth of both the BGA. These findings support the observation of Das and Adhikary, 1996 that organophosphate insecticide is less toxic than organocholorine. Several authors (Rath \& Adhikary, 1994; Goyal et al., 1994; Das \& Adhikary, 1996; Anand \& Subramanian 1997; Kaur \& Ahluwalia, 1997; Kapoor \& Arora, 1998; 2000 a, 2000b; Xia, 2005; Chen et al.,2007; Kumar et al.,2008; Bhattacharyya et al., 2011) have reported inhibitory effect of various pesticides on the growth of cyanobacteria. The inhibition of growth in different concentrations of the pesticides is due to alteration in synthesis of nucleic acids, amino acids and proteins (Kumar et al., 2011) as well as due to impairment in photosynthetic activity (Lal \& Saxena, 1980) of the BGA.

\subsection{Changes in chlorophyl $a$ contents}

Almost all oxygenic photosynthesizer, with the exception of Acaryochloris a cyanobacterium, use chlorophyll a (Björn et al., 2009). The amount of Chl content in the photosynthetic unit of cyanobacterial cell indicates its growth and physiological status. Fig.4 depicts the kinetics of Chl a accumulation and loss in Anabaena sp. and Nostoc sp. treated with different concentrations of Monocrotophos (Fig.4B) and Endosulfan (Fig.4A) in the BG11 medium over 15 days of incubation along with the control. The kinetics pattern was closely similar to 


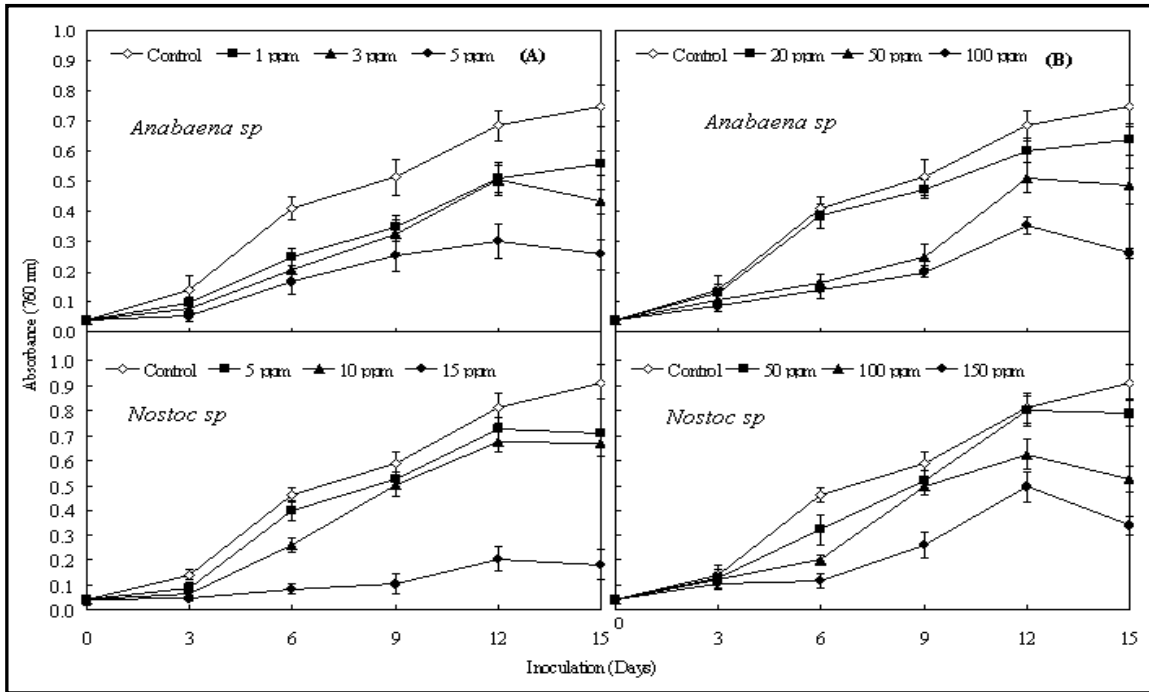

Figure 3. Effect of different concentration of Endosulfan (A) \& Monocrotophos (B) on growth of Anabaena and Nostoc cultured under laboratory condition.

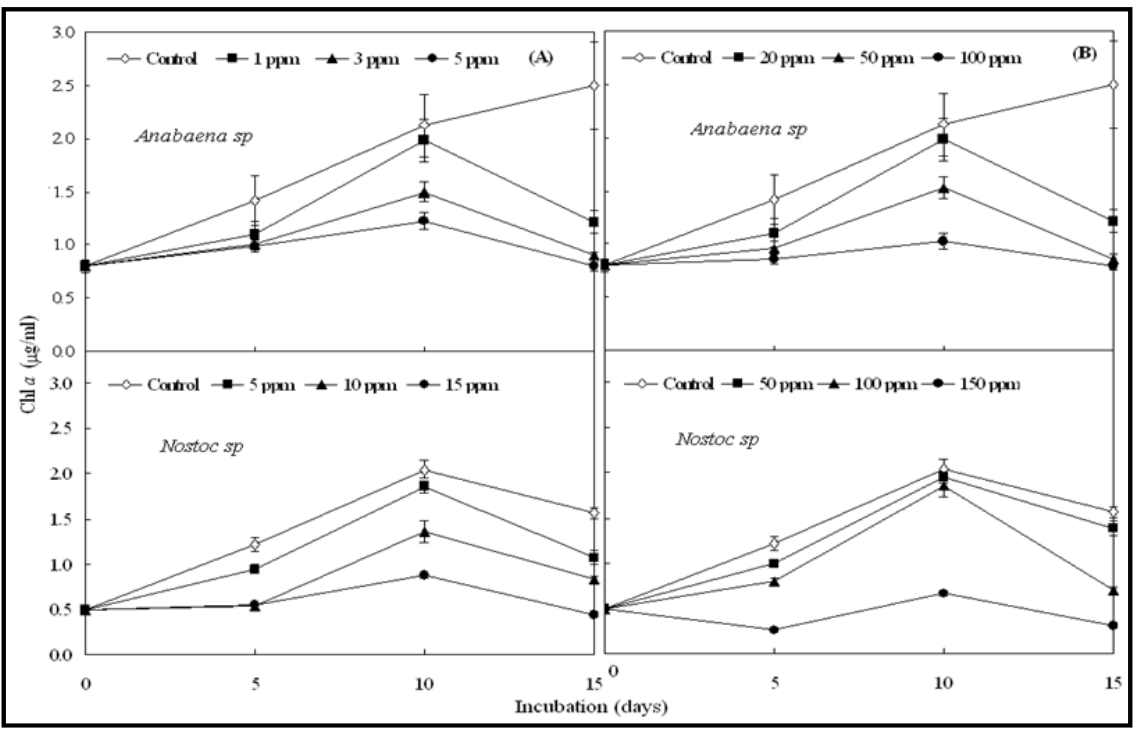

Figure 4. Effect of different concentration of Endosulfan(A) \& Monocrotophos (B) on Chl a of Anabaena and Nostoc cultured under laboratory condition.

that of growth kinetics with minor variations for both the treated and control samples. Except in Anabaena (control sample), the Chl a content reached its maximum level on the 10th day of incubation followed by decline both in control and treated samples. The rate of pigment loss in treated sample was more than that of control. As indicated from the levels, the 
pigment synthesis was very less in Anabaena with 100 ppm Monocrotophos, 5ppm Endosulfan and Nostoc with 150 ppm Monocrotophos, 15 ppm Endosulfan treatment. In these two concentration of pesticides the pigment levels were almost same with the initial level of the pigment in both the samples through out the experimental period of 15 days. The Chl a content was maximum on 10th day though growth rate was maximum at 12th day of incubation. The pigment content declined after 10th day of incubation in all treated samples and control of Nostoc sp. On the other hand, except in the control samples of Anabaena sp. pigment level was highest on 10th day then followed by a sharp decline.

The data indicates that Chl $a$ accumulation and loss in the present study is also time and concentration dependent manner (Fig 4). The pesticides are known to interfere with the synthesis of Chl a pigment by inhibiting the formation of porphyrin rings (Moreland, 1980; Lal and Saxena, 1980). In the present work, the low level of Chl in pesticide treated samples supports the observations of Das \& Adhikary, 1996, Megharaj et al., 2011, Kumar et al., 2008, Battah et al., 2001; Sikha \& Singh, 2004 and Xia, 2005.

\subsection{Changes in electron transport activity}

The DCPIP photoreduction reflects the photochemical potential of PS II. The activities also reflect the coupling between light absorption and photochemical reaction of the thylakoid membrane. In the present study the rate of dye reduction in control and pesticides treated samples of both the alga resemble with the kinetics of Chl $a$ accumulation and loss. The rate of dye reduction in treated samples is low compared to the control (Table 2 and 3). This could be due to loss of pigments and protein content of the organism under the pesticide treated conditions due to stress-induced formation of ROS (Behera \& Choudhury, 2001; Hideg \& Vass, 1996) and possible changes in the thylakoid microenvironment. The degradation of D1 protein under stress condition may be another reason (Long \& Humphries, 1994). These observations are similar to the findings of Shikha and Singh, 2004, Bhattacharyya et al., 2011.

\begin{tabular}{|c|c|c|c|c|c|c|c|c|c|c|c|}
\hline \multicolumn{12}{|c|}{$\mu$ mol of DCPIP Reduced (Anabaena $s p$ ) } \\
\hline Treatment & \begin{tabular}{|l}
$\begin{array}{l}\text { Dose } \\
(\mathrm{ppm})\end{array}$ \\
\end{tabular} & 0 day & 5 day & 10 day & 15 day & Treatment & \begin{tabular}{|l}
$\begin{array}{l}\text { Dose } \\
(\mathrm{ppm})\end{array}$ \\
\end{tabular} & 0 day & 5 day & 10 day & 15 day \\
\hline Control & & $20 \pm 1.2$ & $101 \pm 3.6$ & $175 \pm 3.5$ & $241 \pm 5.5$ & Control & & $20 \pm 1.2$ & $101 \pm 1.8$ & $175 \pm 5.9$ & $241 \pm 8.5$ \\
\hline \multirow{3}{*}{ Monocrotophos } & 20 & $20 \pm 1.2$ & $94 \pm 2.7$ & $180 \pm 6.2$ & $152 \pm 2.9$ & \multirow{3}{*}{ Endosulfan } & 1 & $20 \pm 1.2$ & $91 \pm 22$ & $165 \pm 8$ & $135 \pm 6$ \\
\hline & 50 & $20 \pm 1.2$ & $83 \pm 1.1$ & $140 \pm 2.8$ & $132 \pm 3.6$ & & 2 & $20 \pm 1.2$ & $80 \pm 0.8$ & $120 \pm 3$ & $110 \pm 7$ \\
\hline & 100 & $20 \pm 1.2$ & $65 \pm 5.3$ & $95 \pm 3.3$ & $85 \pm 2.6$ & & 3 & $20 \pm 1.2$ & $65 \pm 1.6$ & $95 \pm 5$ & $75 \pm 3$ \\
\hline
\end{tabular}

Table 2. Electron transport efficiency of PS II in terms of DCPIP photoreduction of Anabaena sp grown under different concentrations of Monocrotophos and Endosulfan in laboratory condition. $( \pm S D)$

\begin{tabular}{|c|c|c|c|c|c|c|c|c|c|c|c|}
\hline \multicolumn{12}{|c|}{$\mu$ mol of DCPIP Reduced (Nostoc Sp) } \\
\hline Treatment & $\begin{array}{l}\text { Dose } \\
(p p m)\end{array}$ & 0 day & 5 day & 10 day & 15 day & Treatment & $\begin{array}{l}\text { Dose } \\
(\mathrm{ppm})\end{array}$ & 0 day & 5 day & 10 day & 15 day \\
\hline Control & & $29 \pm 2.6$ & $145.8 \pm 4.2$ & $190 \pm 8$ & $142 \pm 6.5$ & Control & & $29 \pm 2.6$ & $145.8 \pm 7$ & $190 \pm 11$ & $142 \pm 8.2$ \\
\hline \multirow{3}{*}{ Monocrotophos } & 50 & $29 \pm 2.6$ & $94 \pm 6$ & $126 \pm 6$ & $84 \pm 3.2$ & \multirow{3}{*}{ Endosulfan } & 5 & $29 \pm 2.6$ & $100.8 \pm 3.8$ & $116 \pm 7$ & $54.6 \pm 5$ \\
\hline & 100 & $29 \pm 2.6$ & $55.5 \pm 4$ & $96 \pm 7$ & $49.6 \pm 3.6$ & & 10 & $29 \pm 2.6$ & $84 \pm 3.3$ & $102 \pm 6$ & $50 \pm 6$ \\
\hline & 150 & $29 \pm 2.6$ & $25.2 \pm 2.6$ & $45.8 \pm 5.4$ & $30 \pm 6$ & & 15 & $29 \pm 2.6$ & $82 \pm 3.4$ & $94 \pm 8$ & $32.4 \pm 4$ \\
\hline
\end{tabular}

Table 3. Electron transport efficiency of PS II in terms of DCPIP photoreduction of Nostoc Sp grown under different concentrations of Monocrotophos and Endosulfan in laboratory condition. ( \pm SD) 


\subsection{Measurement of fluorescence characteristics}

Analyses of fluorescence emission, excitation emission, fluorescence polarization and excitation energy transfer of thylakoids provide information about the structural organization and the microenvironment of thylakoid membrane. The analyses also give information about the degree of coupling of different pigment complexes. Information about the coupling of light absorption and photochemical reactions could also be obtained by monitoring fluorescence characteristics of whole cells of the cyanobacteria. Therefore, to determine the structural and functional status of the thylakoid, fluorescence excitation, emission and polarization measurements are very much important. Campbell et al.,1998 have opined that fluorescence analysis is an integral part of the studies of photosynthesis in BGA. Shikha \& Singh, 2004 have extensively used fluorescence studies to monitor photosynthetic status of A. doliolum treated with herbicide glyophosphate.

Cyanobacteria fluorescence characteristics are distinct from those of plants due to their specific structural and functional properties (Campbell et al., 1998). These include significant fluorescence emission from the light harvesting phycobiliproteins, large and rapid changes in fluorescence yield (state transitions) which depend on metabolic and environmental conditions as well as flexible and overlapping respiratory and photosynthetic electron transport chains. In cyanobacteria, the photosynthetic system is tightly linked to other principal metabolic pathways and is itself a major metabolic sink for iron, nitrogen and carbon skeletons. Therefore, Chl fluorescence signals can provide rapid, real-time information on both photosynthesis and overall acclimation status of cyanobacteria.

\subsubsection{Fluorescence emission}

The fluorescence characteristics of test organisms both in control and insecticides treated samples are shown in Table 4 and 5. There is gradual increase in fluorescence intensity at F685 and F735 in all conditions over 15 days of incubation under laboratory condition except on 5th day of control. The ratios of F685 to F735 increased from 5th day till the end of experiment both in control and treated samples. The ratios were also more in treated samples than in the control. The ratios gradually increased as the concentration of the insecticide and treatment period increased in both the organisms.

\begin{tabular}{|c|c|c|c|c|c|c|c|c|c|c|c|c|c|}
\hline \multicolumn{14}{|c|}{ Fluorescence Intensity (Arbitrary unit) } \\
\hline \multirow{2}{*}{ Treatment } & \multirow{2}{*}{$\begin{array}{l}\text { Dose } \\
(\mathrm{ppm})\end{array}$} & \multicolumn{4}{|c|}{ F685 } & \multicolumn{4}{|c|}{ F735 } & \multicolumn{4}{|c|}{ F685/F735 } \\
\hline & & 0 day & 5 day & 10 day & 15 day & 0 day & 5 day & 10 day & 15 day & 0 day & 5 day & 10 day & 15 day \\
\hline Control & 0 & 91.0 & 88.0 & 137.0 & 195.0 & 26.5 & 25.0 & 30.0 & 36.0 & 3.4 & 3.52 & 4.50 & 5.40 \\
\hline \multirow{3}{*}{$\begin{array}{l}\text { Monocroto } \\
\text { phos }\end{array}$} & 20 & 91.0 & 100.0 & 167.0 & 202.0 & 26.5 & 28.0 & 34.0 & 40.0 & 3.4 & 3.57 & 4.90 & 5.05 \\
\hline & 50 & 91.0 & 122.0 & 178.0 & 240.0 & 26.5 & 32.0 & 36.0 & 42.0 & 3.4 & 3.81 & 4.94 & 5.71 \\
\hline & 100 & 91.0 & 139.0 & 195.0 & 270.0 & 26.5 & 36.0 & 39.0 & 46.0 & 3.4 & 3.86 & 5.00 & 5.84 \\
\hline \multirow{3}{*}{ Endosulfan } & 1 & 91.0 & 110.0 & 183.0 & 299.0 & 26.5 & 27.0 & 37.0 & 54.0 & 3.4 & 4.07 & 4.90 & 5.53 \\
\hline & 3 & 91.0 & 122.0 & 193.0 & 314.0 & 26.5 & 29.0 & 38.0 & 55.0 & 3.4 & 4.20 & 5.07 & 5.70 \\
\hline & 5 & 91.0 & 152.0 & 218.0 & 338.0 & 26.5 & 35.0 & 41.0 & 56.0 & 3.4 & 4.34 & 5.30 & 6.03 \\
\hline
\end{tabular}

Table 4. Chlorophyll a fluorescence emission of Anabaena grown in control and different concentrations of Monocrotophos and Endodahan in laboratory conditions. 


\begin{tabular}{|c|c|c|c|c|c|c|c|c|c|c|c|c|c|}
\hline \multicolumn{14}{|c|}{ Fluorescence Intensity (Arbitrary unit) } \\
\hline \multirow[b]{2}{*}{ Treatment } & \multirow{2}{*}{$\begin{array}{l}\text { Dose } \\
\text { (ppm) }\end{array}$} & \multicolumn{4}{|c|}{ F685 } & \multicolumn{4}{|c|}{ F735 } & \multicolumn{4}{|c|}{ F685/F735 } \\
\hline & & $\begin{array}{c}0 \\
\text { day } \\
\end{array}$ & \begin{tabular}{|c|}
5 \\
day \\
\end{tabular} & $\begin{array}{c}10 \\
\text { day }\end{array}$ & $\begin{array}{c}15 \\
\text { day }\end{array}$ & $\begin{array}{c}0 \\
\text { day }\end{array}$ & $\begin{array}{c}5 \\
\text { day } \\
\end{array}$ & $\begin{array}{c}10 \\
\text { day }\end{array}$ & $\begin{array}{c}15 \\
\text { day }\end{array}$ & $\begin{array}{c}0 \\
\text { day }\end{array}$ & $\begin{array}{c}5 \\
\text { day } \\
\end{array}$ & $\begin{array}{c}10 \\
\text { day }\end{array}$ & $\begin{array}{c}15 \\
\text { day }\end{array}$ \\
\hline Control & & 97.5 & 92.0 & 146.0 & 204.0 & 21.6 & 20.0 & 24.6 & 34.0 & 4.5 & 4.6 & 5.9 & 6.0 \\
\hline \multirow{3}{*}{ Monocrotophos } & 50 & 97.5 & 108.0 & 177.0 & 220.0 & 21.6 & 22.1 & 29.0 & 36.0 & 4.5 & 4.9 & 6.1 & 6.1 \\
\hline & 100 & 97.5 & 134.0 & 188.0 & 257.0 & 21.6 & 25.2 & 30.3 & 39.1 & 4.5 & 5.3 & 6.2 & 6.6 \\
\hline & 150 & 97.5 & 147.0 & 203.0 & 284.0 & 21.6 & 26.3 & 31.7 & 42.3 & 4.5 & 5.6 & 6.4 & 6.7 \\
\hline \multirow{3}{*}{ Endosulfan } & 5 & 97.5 & 102.0 & 151.0 & 280.0 & 21.6 & 21.8 & 25.0 & 44.0 & 4.5 & 4.7 & 6.0 & 6.4 \\
\hline & 10 & 97.5 & 114.0 & 164.0 & 294.0 & 21.6 & 21.6 & 24.8 & 42.5 & 4.5 & 5.3 & 6.6 & 6.9 \\
\hline & 15 & 97.5 & 148.0 & 198.0 & 328.0 & 21.6 & 26.6 & 28.4 & 45.8 & 4.5 & 5.6 & 6.6 & 7.1 \\
\hline
\end{tabular}

Table 5. Chlorophyll $a$ fluorescence emission of Nostoc grown in control and different concentrations of Monocrotophos and Endodahan in laboratory conditions.

Chlorophyll $a$ fluorescence emission spectra of whole algal cells measured at room temperature exhibit usually two emission maxima, the first at 685 (F685) nm and the second at 735 (F735) nm. F685 is considered as the emission from PS II and F735 from PS I (Papageorgiou, 1975). A gradual increase in fluorescence intensity (Table 4 and 5) at $685 \mathrm{~nm}$ (F685) and 735 $\mathrm{nm}$ (F735) is observed over 15 days of incubation of both the alga in control as well as insecticides treated samples. Increase in fluorescence intensity particularly during developmental stage has been ascribed due to improved organization of light harvesting (antenna) complexes of the thylakoid which results in trapping of more solar energy. However, if proportional increase in the photochemical activity will not take place, then the absorbed energy is emitted as fluorescence (Krause \& Weis, 1991; Krieger et al., 1992). On the other hand, uncoupling of the photosynthetic pigments and RC during natural ageing or under stress conditions may also lead to increase in the fluorescence intensity. Continuous increase in the fluorescence intensity in the control sample could be due to higher trapping of solar energy as the algal cell improves their thylakoid organization during the culture. However, without proportional increase in photochemical activities, the excitation energy is emitted as fluorescence. On the other hand increase in the fluorescence intensity in the insecticides treated samples is much higher than the control. This suggests that the pesticides have induced uncoupling of light harvesting system and electron transport resulting emission of excitation energy as fluorescence. Higher susceptibility of PS II compared to PS I to different stress such as water stress (Deo and Biswal, 1998), light stress (Behera et al., 2002), oxidation stress (Behera and Choudhury, 2001) etc. have been reported in different plant systems. The gradual increase in the ratio of F685 and F735, when the concentration of pesticides increase suggests that PS II is more affected by the treatments.

\subsubsection{Fluorescence excitation}

Table-6 depicts the effect of different concentrations of pesticides on the ratio of peak heights of fluorescence excitation emission of Anabaena sp. The ratios of $471 \mathrm{~nm}$ to $439 \mathrm{~nm}$ and $485 \mathrm{~nm}$ to $439 \mathrm{~nm}$ increased throughout the 15 days of incubation in all concentrations of Monocrotophos and Endosulfan used along with the control sample. However, compared 
to the control, the ratio declined with insecticide treatment as well as with the increase in concentration of both pesticides.

\begin{tabular}{|c|c|c|c|c|c|c|c|c|c|}
\hline \multirow[b]{3}{*}{ Treatment } & \multirow{3}{*}{$\begin{array}{c}\text { Dose } \\
(\mathrm{ppm})\end{array}$} & \multicolumn{8}{|c|}{ Ratio of Peak Heights(a.u) } \\
\hline & & \multicolumn{4}{|c|}{ E471/E439 } & \multicolumn{4}{|c|}{ E485/E439 } \\
\hline & & 0 day & 5 day & 10 day & 15 day & 0 day & 5 day & 10 day & 15 day \\
\hline Control & & 0.489 & 0.988 & 1.213 & 1.500 & 0.625 & 1.195 & 1.325 & 1.632 \\
\hline \multirow{3}{*}{ Monocrotophos } & 20 & 0.489 & 0.940 & 1.208 & 1.478 & 0.625 & 1.010 & 1.217 & 1.417 \\
\hline & 50 & 0.489 & 0.891 & 1.112 & 1.155 & 0.625 & 0.921 & 1.200 & 1.253 \\
\hline & 100 & 0.489 & 0.695 & 0.789 & 0.918 & 0.625 & 0.900 & 1.182 & 1.208 \\
\hline \multirow{3}{*}{ Endosulfan } & 1 & 0.489 & 0.825 & 1.094 & 1.132 & 0.625 & 1.093 & 1.131 & 1.348 \\
\hline & 3 & 0.489 & 0.821 & 1.087 & 1.021 & 0.625 & 0.956 & 1.121 & 1.187 \\
\hline & 5 & 0.489 & 0.624 & 0.721 & 0.802 & 0.625 & 0.795 & 0.860 & 0.934 \\
\hline
\end{tabular}

Table 6. Effect of different concentrations of Monocrotophos and Endosulfan on ratio of peak heights of fluorescence excitation of Anabaena grown in laboratory conditions.

The ratio of peak heights of fluorescence excitation emission of Nostoc sp. is represented in Table-7 both in control and pesticides treated (50, 100 and 150 ppm of Monocrotophos and 5, 10 and 15 ppm of Endosulfan) samples over 15 days of incubation under laboratory condition. Similar trend of increase in the ratio of $471 \mathrm{~nm}$ to $439 \mathrm{~nm}$ was also noted in Monocrotophos and Endosulfan treated samples as well as in control over 15 days of incubation. However, the increase was less in insecticide treated samples and more so when the concentration of the insecticide was more. On the other hand, except in control, no definite increasing or decreasing trend in the ratio of $485 \mathrm{~nm}$ to $439 \mathrm{~nm}$ was noted in the treated samples.

\begin{tabular}{|l|c|c|c|c|c|c|c|c|c|}
\hline \multirow{3}{*}{ Treatment } & \multirow{2}{*}{$\begin{array}{c}\text { Dose } \\
(\mathrm{ppm})\end{array}$} & \multicolumn{6}{|c|}{ Eatio of Peak Heights(a.u) } \\
\cline { 3 - 10 } & & 0 day & 5 day & 10 day & 15 day & 0 day & 5 day & 10 day & 15 day \\
\cline { 3 - 10 } & 0 & 0.627 & 1.055 & 1.368 & 1.600 & 1.304 & 1.505 & 1.602 & 1.678 \\
\hline Control & 50 & 0.627 & 1.040 & 1.150 & 1.320 & 1.304 & 1.202 & 1.310 & 1.408 \\
\hline \multirow{3}{*}{ Monocrotophos } & 100 & 0.627 & 0.932 & 0.983 & 1.152 & 1.304 & 1.084 & 1.093 & 1.101 \\
\cline { 2 - 10 } & 150 & 0.627 & 0.729 & 0.765 & 0.997 & 1.304 & 0.935 & 1.012 & 1.087 \\
\hline \multirow{3}{*}{ Endosulfan } & 5 & 0.627 & 0.757 & 0.925 & 1.162 & 1.304 & 1.454 & 0.835 & 1.303 \\
\cline { 2 - 10 } & 10 & 0.627 & 0.747 & 0.854 & 1.051 & 1.304 & 1.359 & 0.519 & 1.131 \\
\cline { 2 - 10 } & 15 & 0.627 & 0.629 & 0.765 & 0.908 & 1.304 & 0.909 & 0.429 & 0.933 \\
\hline
\end{tabular}

Table 7. Effect of different concentrations of Monocrotophos and Endosulfan on ratio of peak heights of fluorescence excitation of Nostoc grown in laboratory conditions.

The study of fluorescence excitation characteristics of chloroplast is used to explain the spatial arrangement and coupling of different pigment molecules in the thylakoid membrane (Behera \& Choudhury, 1997). The changes in the relative peak values of fluorescence excitation at 471 (E471) $\mathrm{nm}$ and 485 (E485) $\mathrm{nm}$ with reference to peak at 439 (E439) nm reflects the alterations in pigment protein complexes in the thylakoid domain during development of the organism. Table 6 and 7 indicate the changes in the ratio of peak heights in control and with different concentration of Monocrotophos and Endosulfan. The decrease in the ratio of $471 \mathrm{~nm}$ to 439 
$\mathrm{nm}$ is attributed to gradual decrease in coupling between Chl and Car with the increase of the duration of incubation period with the insecticides.

\subsubsection{Efficiency of energy transfer}

The simple and direct proof of excitation energy transfer from Car and phycobilisomes (PBS) to Chl comes from the contribution of the light absorbed by the Car and PBS in Chl $a$ fluorescence. At shorter wavelength, only Chl, Car and PBS and at longer wavelength only $\mathrm{Chl}$ is responsible for the absorption. There is a significant decline in the capacity of energy transfer in PS II for all concentrations of Monocrotophos and Endosulfan in both the alga compared to the control (Table 8 and 9). The temporal kinetics of energy transfer follows similar pattern like the kinetics of DCPIP photoreduction (Table 2 and 3) and photosynthetic efficiency of PS II during the 15 days of incubation. The decrease in the Chl a contents in the insecticide treated samples (Fig. 4) may be correlated to certain conformational changes in the pigment protein complex in the photosystem in turns affecting the excitation energy transfer (Gruszescki et al., 1991). The energy transfer from Car to Chl is increasingly hampered (Table 8 and 9) as the concentration of the pesticides increased.

Though the values are different, the kinetics of energy transfer in PS I is similar to that of PS II for both Anabaena sp. and Nostoc sp. in control and treated samples. However, compared to PS II, PS I is less susceptible to the insecticide treatment in both the alga. Smaller changes in excitation energy transfer in PS I suggest that PS I is less effected even under stress condition. Relatively less susceptibility of PS I compared to PS II to various stress conditions has been shown earlier by various authors (Choudhury \& Choe, 1996; Deo \& Biswal, 1998; Campbell et al., 1998; Behera et al., 2002)

\begin{tabular}{|c|c|c|c|c|c|c|c|c|c|}
\hline \multirow{3}{*}{ Treatment } & \multirow{3}{*}{ Dose (ppm) } & \multicolumn{8}{|c|}{ Efficiency of excitation energy transfer (a.u) } \\
\hline & & \multicolumn{4}{|c|}{ PS II } & \multicolumn{4}{|c|}{ PS I } \\
\hline & & 0 day & 5 day & 10 day & 15 day & 0 day & 5 day & 10 day & 15 day \\
\hline Control & 0 & $\begin{array}{c}1.48 \\
(100)\end{array}$ & $\begin{array}{c}1.95 \\
(131)\end{array}$ & $\begin{array}{c}2.15 \\
(145)\end{array}$ & $\begin{array}{c}2.10 \\
(142)\end{array}$ & $\begin{array}{c}1.22 \\
(100)\end{array}$ & $\begin{array}{c}1.64 \\
(134)\end{array}$ & $\begin{array}{c}1.83 \\
(150)\end{array}$ & $\begin{array}{l}1.80 \\
(147)\end{array}$ \\
\hline \multirow{3}{*}{ Monocrotophos } & 20 & $\begin{array}{c}1.48 \\
(100)\end{array}$ & $\begin{array}{c}1.87 \\
(126) \\
\end{array}$ & $\begin{array}{c}2.00 \\
(135)\end{array}$ & $\begin{array}{c}1.92 \\
(130)\end{array}$ & $\begin{array}{c}1.22 \\
(100)\end{array}$ & $\begin{array}{c}1.59 \\
(130) \\
\end{array}$ & $\begin{array}{c}1.74 \\
(143)\end{array}$ & $\begin{array}{c}1.69 \\
(138)\end{array}$ \\
\hline & 50 & $\begin{array}{c}1.48 \\
(100)\end{array}$ & $\begin{array}{c}1.75 \\
(118)\end{array}$ & $\begin{array}{c}1.93 \\
(130) \\
\end{array}$ & $\begin{array}{c}1.80 \\
(122) \\
\end{array}$ & $\begin{array}{c}1.22 \\
(100)\end{array}$ & $\begin{array}{c}1.52 \\
(125)\end{array}$ & $\begin{array}{c}1.67 \\
(137)\end{array}$ & $\begin{array}{c}1.58 \\
(130)\end{array}$ \\
\hline & 100 & $\begin{array}{c}1.48 \\
(100)\end{array}$ & $\begin{array}{l}1.67 \\
(112)\end{array}$ & $\begin{array}{l}1.70 \\
(114)\end{array}$ & $\begin{array}{c}1.62 \\
(109)\end{array}$ & $\begin{array}{c}1.22 \\
(100)\end{array}$ & $\begin{array}{c}1.41 \\
(116)\end{array}$ & $\begin{array}{c}1.52 \\
(125)\end{array}$ & $\begin{array}{c}1.46 \\
(120)\end{array}$ \\
\hline \multirow[t]{3}{*}{ Endosulfan } & 1 & $\begin{array}{c}1.48 \\
(100)\end{array}$ & $\begin{array}{c}1.82 \\
(123)\end{array}$ & $\begin{array}{c}1.98 \\
(134)\end{array}$ & $\begin{array}{c}1.88 \\
(127)\end{array}$ & $\begin{array}{c}1.22 \\
(100)\end{array}$ & $\begin{array}{c}1.58 \\
(129)\end{array}$ & $\begin{array}{c}1.70 \\
(149)\end{array}$ & $\begin{array}{c}1.67 \\
(137)\end{array}$ \\
\hline & 3 & $\begin{array}{c}1.48 \\
(100)\end{array}$ & $\begin{array}{c}1.70 \\
(115)\end{array}$ & $\begin{array}{l}1.87 \\
(126)\end{array}$ & $\begin{array}{c}1.82 \\
(123)\end{array}$ & $\begin{array}{c}1.22 \\
(100)\end{array}$ & $\begin{array}{l}1.54 \\
(126)\end{array}$ & $\begin{array}{c}1.64 \\
(134)\end{array}$ & $\begin{array}{l}1.56 \\
(128)\end{array}$ \\
\hline & 5 & $\begin{array}{c}1.48 \\
(100) \\
\end{array}$ & $\begin{array}{c}1.55 \\
(105) \\
\end{array}$ & $\begin{array}{c}1.64 \\
(111) \\
\end{array}$ & $\begin{array}{c}1.60 \\
(108) \\
\end{array}$ & $\begin{array}{c}1.22 \\
(100) \\
\end{array}$ & $\begin{array}{c}1.46 \\
(120) \\
\end{array}$ & $\begin{array}{c}1.54 \\
(126) \\
\end{array}$ & $\begin{array}{c}1.50 \\
(122) \\
\end{array}$ \\
\hline
\end{tabular}

Table 8. Efficiency of excitation energy transfer from carotenoids to chlorophyll of PS II and PS I of Anabaena grown under control and different concentrations of Monocrotophos and Endosulfan in laboratory conditions. 


\begin{tabular}{|c|c|c|c|c|c|c|c|c|c|}
\hline \multirow{3}{*}{ Treatment } & \multirow{3}{*}{ Dose (ppm) } & \multicolumn{8}{|c|}{ Efficiency of excitation energy transfer (a.u) } \\
\hline & & \multicolumn{4}{|c|}{ PS II } & \multicolumn{4}{|c|}{ PS I } \\
\hline & & 0 day & 5 day & 10 day & 15 day & 0 day & 5 day & 10 day & 15 day \\
\hline Control & 0 & $\begin{array}{l}0.558 \\
(100)\end{array}$ & $\begin{array}{l}0.714 \\
(128)\end{array}$ & $\begin{array}{l}0.822 \\
(147)\end{array}$ & $\begin{array}{l}0.812 \\
(145)\end{array}$ & $\begin{array}{l}0.469 \\
(100)\end{array}$ & $\begin{array}{l}0.615 \\
(131)\end{array}$ & $\begin{array}{l}0.724 \\
(154)\end{array}$ & $\begin{array}{l}0.703 \\
(150)\end{array}$ \\
\hline \multirow{3}{*}{ Monocrotophos } & 20 & $\begin{array}{l}0.558 \\
(100) \\
\end{array}$ & $\begin{array}{l}0.708 \\
(127) \\
\end{array}$ & $\begin{array}{l}0.794 \\
(142) \\
\end{array}$ & $\begin{array}{l}0.760 \\
(136)\end{array}$ & $\begin{array}{l}0.469 \\
(100) \\
\end{array}$ & $\begin{array}{l}0.600 \\
(128) \\
\end{array}$ & $\begin{array}{l}0.613 \\
(146) \\
\end{array}$ & $\begin{array}{l}0.656 \\
(140) \\
\end{array}$ \\
\hline & 50 & $\begin{array}{l}0.558 \\
(100)\end{array}$ & $\begin{array}{l}0.675 \\
(121) \\
\end{array}$ & $\begin{array}{l}0.730 \\
(131)\end{array}$ & $\begin{array}{l}0.712 \\
(127)\end{array}$ & $\begin{array}{l}0.469 \\
(100) \\
\end{array}$ & $\begin{array}{l}0.572 \\
(122)\end{array}$ & $\begin{array}{l}0.637 \\
(136)\end{array}$ & $\begin{array}{l}0.609 \\
(130)\end{array}$ \\
\hline & 100 & $\begin{array}{l}0.558 \\
(100)\end{array}$ & $\begin{array}{l}0.655 \\
(113)\end{array}$ & $\begin{array}{l}0.647 \\
(116)\end{array}$ & $\begin{array}{l}0.608 \\
(109)\end{array}$ & $\begin{array}{l}0.469 \\
(100)\end{array}$ & $\begin{array}{l}0.539 \\
(115)\end{array}$ & $\begin{array}{l}0.562 \\
(120)\end{array}$ & $\begin{array}{l}0.529 \\
(113)\end{array}$ \\
\hline \multirow[t]{3}{*}{ Endosulfan } & 5 & $\begin{array}{l}0.558 \\
(100) \\
\end{array}$ & $\begin{array}{l}0.704 \\
(126) \\
\end{array}$ & $\begin{array}{l}0.783 \\
(140) \\
\end{array}$ & $\begin{array}{l}0.753 \\
(135) \\
\end{array}$ & $\begin{array}{l}0.469 \\
(100) \\
\end{array}$ & $\begin{array}{l}0.605 \\
(129) \\
\end{array}$ & $\begin{array}{l}0.680 \\
(145) \\
\end{array}$ & $\begin{array}{l}0.656 \\
(140) \\
\end{array}$ \\
\hline & 10 & $\begin{array}{l}0.558 \\
(100)\end{array}$ & $\begin{array}{l}0.671 \\
(120)\end{array}$ & $\begin{array}{l}0.725 \\
(130)\end{array}$ & $\begin{array}{l}0.704 \\
(126)\end{array}$ & $\begin{array}{l}0.469 \\
(100)\end{array}$ & $\begin{array}{l}0.586 \\
(125)\end{array}$ & $\begin{array}{l}0.635 \\
(136)\end{array}$ & $\begin{array}{l}0.609 \\
(130)\end{array}$ \\
\hline & 15 & $\begin{array}{l}0.558 \\
(100)\end{array}$ & $\begin{array}{l}0.619 \\
(111)\end{array}$ & $\begin{array}{l}0.636 \\
(114)\end{array}$ & $\begin{array}{l}0.638 \\
(110)\end{array}$ & $\begin{array}{l}0.469 \\
(100)\end{array}$ & $\begin{array}{l}0.558 \\
(119)\end{array}$ & $\begin{array}{l}0.572 \\
(122)\end{array}$ & $\begin{array}{l}0.548 \\
(117)\end{array}$ \\
\hline
\end{tabular}

Table 9. Efficiency of excitation energy transfer from carotenoids to chlorophyll of PS II and PS I of Nostoc grown under control and different concentrations of Monocrotophos and Endosulfan in laboratory conditions.

\subsubsection{Fluorescence polarization}

Changes in fluorescence polarization of the two algal species under control and insecticides treated conditions give further information on the status of pigment-protein complexes with reference to their microenvironment in thylakoid membrane. The increase in polarization during the initial stage of incubation in all treated samples compared to the control (Fig.5 ) could be due to the poor coupling between the pigment protein complex and RC (Behera \& Choudhury, 1997). On the other hand, increase in polarization in the later phase of growth (10-15 days of incubation) could be due to disorganization of pigment protein complexes and $\mathrm{RC}$, leading to a decrease in quantum migration. Alternatively, peroxidation of lipid during later stage may induce gel phase of the thylakoid membranes restricting the mobility of Chl dipole (Panda \& Biswal, 1989 and 1990). This may cause an increase in the polarization value at 100 and $150 \mathrm{ppm}$ of Monocrotophos and 5 and 15 ppm of Endosulfan treatment to the Anabaena sp and Nostoc sp. respectively. Significant high levels of polarization suggests a greater disorganization of thylakoid membrane due to high lipid peroxidation (Kumar et al., 2008).

\subsubsection{Photosynthetic efficiency}

Photosynthetic efficiency of PS II can be measured by monitoring the ratio Fv/Fm. It is known that photoinhibition occurs when the rate of excitation energy captured exceeds the rate of consumption in photosynthetic reactions (Osmond, 1981; Powles, 1984). Photoinhibition in terms of Fv/Fm has been found both in higher plants (Panda et al., 2006; Rodrigues et al., 2007) as well as in algae (Ying and Hader, 2002; Xia, 2005; Chen et al., 2007). 


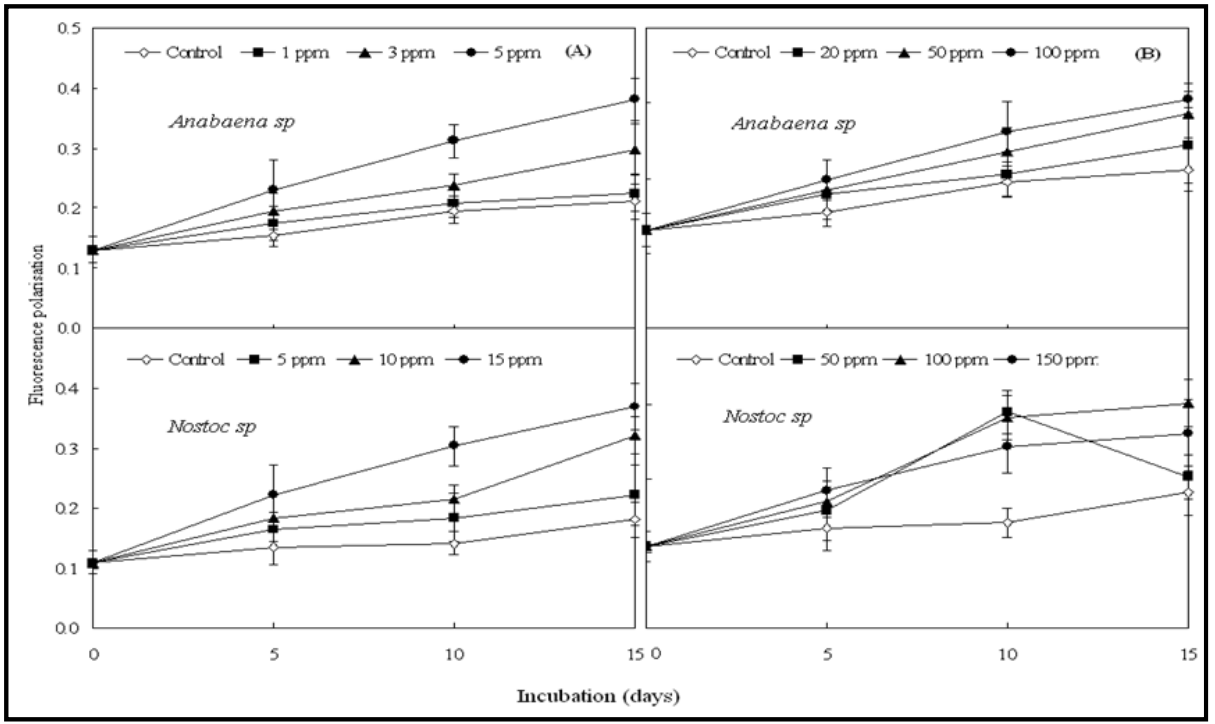

Figure 5. Effect of different concentration of Endosulfan(A) \& Monocrotophos (B)on fluorescence polarization of Nostoc and Anabaena cultured under laboratory condition.

The primary site of photoinhibition is the reaction centre (D1 protein) of PS II (Demming and Bjorkman, 1987; Jordan, 1996). Photoinhibition is manifested as a decrease in oxygen evolution (Krause, 1988) and photochemical efficiency (Falk and Samuelsson, 1992). The data on the measurement of Fv/Fm during the laboratory incubation of the different samples (Table 10 and 11) show similar kinetics like that off the photosynthetic pigment and protein accumulation and loss and DCPIP photoreduction of both the BGA in control and treated (pesticide) samples. As the concentration of pesticides increased, photosynthetic efficiency decreased. This shows that both the species of cyanobacteria are sensitive to higher concentration of pesticides. Pesticides, particularly at higher concentration may (directly or indirectly) cause damage to D1 protein of PS II leading to photoinhibition. The decrease in Fv/Fm ratio in pesticide treated sample could also be due to decrease in Phycocyanin, Phycoerythrin and Allophycocyanin content, which results in a decrease of light energy absorption by phycobilisomes and reduction of photochemical efficiency (Fv/Fm) of PS II. Similar observations have been reported by Xia, 2005 in N. sphaeroids. The present finding is in confirmatory to the observation of Xia, 2005. 


\begin{tabular}{|c|c|c|c|c|c|c|c|c|c|c|c|}
\hline \multicolumn{12}{|c|}{ PS II efficiency } \\
\hline \multicolumn{12}{|l|}{ Nostoc } \\
\hline Treatment & $\begin{array}{l}\text { Dose } \\
(p p m)\end{array}$ & \begin{tabular}{|l|}
0 \\
day
\end{tabular} & \begin{tabular}{|l|}
5 \\
day
\end{tabular} & $\begin{array}{l}10 \\
\text { day }\end{array}$ & $\begin{array}{l}15 \\
\text { day }\end{array}$ & Treatment & $\begin{array}{l}\text { Dose } \\
(p p m)\end{array}$ & $\begin{array}{l}0 \\
\text { day }\end{array}$ & $\begin{array}{l}5 \\
\text { day }\end{array}$ & $\begin{array}{l}10 \\
\text { day }\end{array}$ & $\begin{array}{l}15 \\
\text { day }\end{array}$ \\
\hline Control & & $\begin{array}{l}0.370 \\
(100) \\
\end{array}$ & $\begin{array}{l}0.524 \\
(142)\end{array}$ & $\begin{array}{l}0.562 \\
(152)\end{array}$ & \begin{tabular}{|l|}
0.536 \\
$(145)$
\end{tabular} & Control & & $\begin{array}{l}0.370 \\
(100)\end{array}$ & \begin{tabular}{|l}
0.524 \\
$(142)$
\end{tabular} & \begin{tabular}{|l}
0.562 \\
$(152)$
\end{tabular} & $\begin{array}{l}0.536 \\
(145)\end{array}$ \\
\hline \multirow{3}{*}{ Monocrotophos } & 50 & $\begin{array}{l}0 . \\
370 \\
(100)\end{array}$ & $\begin{array}{l}0.500 \\
(135)\end{array}$ & $\begin{array}{l}0.515 \\
(139)\end{array}$ & $\begin{array}{l}0.473 \\
(128)\end{array}$ & \multirow{3}{*}{ Endosulfan } & 5 & $\begin{array}{l}0.370 \\
(100)\end{array}$ & $\begin{array}{l}0.458 \\
(124)\end{array}$ & $\begin{array}{l}0.520 \\
(141)\end{array}$ & $\begin{array}{l}0.467 \\
(126)\end{array}$ \\
\hline & 100 & \begin{tabular}{|l|}
. \\
370 \\
$(100)$ \\
\end{tabular} & $\begin{array}{l}0.431 \\
(116)\end{array}$ & $\begin{array}{l}0.500 \\
(135)\end{array}$ & $\begin{array}{l}0.429 \\
(116)\end{array}$ & & 10 & $\begin{array}{l}0.370 \\
(100)\end{array}$ & $\begin{array}{l}0.387 \\
(105)\end{array}$ & $\begin{array}{l}0.455 \\
(123)\end{array}$ & $\begin{array}{l}0.375 \\
(101)\end{array}$ \\
\hline & 150 & $\begin{array}{l}0 . \\
370 \\
(100)\end{array}$ & $\begin{array}{l}0.375 \\
(101)\end{array}$ & $\begin{array}{l}0.404 \\
(109)\end{array}$ & $\begin{array}{l}0.387 \\
(105)\end{array}$ & & 15 & $\begin{array}{l}0.370 \\
(100)\end{array}$ & $\begin{array}{l}0.313 \\
(85)\end{array}$ & $\begin{array}{l}0.333 \\
(90)\end{array}$ & $\begin{array}{l}0.316 \\
(85)\end{array}$ \\
\hline
\end{tabular}

Table 10. Photosynthetic efficiency (in term of $\mathrm{F}_{\mathrm{v}} / \mathrm{F}_{\mathrm{m}}$ ) of PS II of Nostoc grown under different concentrations of Monocrotophos and Endosulfan in laboratory condition.

\begin{tabular}{|c|c|c|c|c|c|c|c|c|c|c|c|}
\hline \multicolumn{12}{|l|}{ Anabaena } \\
\hline Treatment & $\begin{array}{l}\text { Dose } \\
(\mathrm{ppm})\end{array}$ & $\begin{array}{l}0 \\
\text { day }\end{array}$ & \begin{tabular}{|l}
5 \\
day
\end{tabular} & $\begin{array}{l}10 \\
\text { day }\end{array}$ & 15 day & Treatment & $\begin{array}{l}\text { Dose } \\
(\mathrm{ppm})\end{array}$ & $\begin{array}{l}0 \\
\text { day }\end{array}$ & 5 day & 10 day & 15 day \\
\hline Control & & \begin{tabular}{|l}
0.350 \\
$(100)$ \\
\end{tabular} & $\begin{array}{l}0.520 \\
(149) \\
\end{array}$ & $\begin{array}{l}0.556 \\
(159) \\
\end{array}$ & $\begin{array}{l}0.515 \\
(147) \\
\end{array}$ & Control & & $\begin{array}{l}0.350 \\
(100) \\
\end{array}$ & \begin{tabular}{|l|}
0.520 \\
$(149)$ \\
\end{tabular} & $\begin{array}{l}0.556 \\
(159) \\
\end{array}$ & \begin{tabular}{|l|}
0.515 \\
$(147)$ \\
\end{tabular} \\
\hline \multirow{3}{*}{ Monocrotophos } & 20 & \begin{tabular}{|l|}
0. \\
350 \\
$(100)$ \\
\end{tabular} & $\begin{array}{l}0.482 \\
(138)\end{array}$ & $\begin{array}{l}0.500 \\
(143)\end{array}$ & $\begin{array}{l}0.468 \\
(142)\end{array}$ & \multirow{3}{*}{ Endosulfan } & 1 & $\begin{array}{l}0.350 \\
(100)\end{array}$ & $\begin{array}{l}0.404 \\
(115)\end{array}$ & $\begin{array}{l}0.511 \\
(146)\end{array}$ & $\begin{array}{l}0.455 \\
(130)\end{array}$ \\
\hline & 50 & $\begin{array}{l}0 . \\
350 \\
(100) \\
\end{array}$ & $\begin{array}{l}0.442 \\
(126)\end{array}$ & $\mid \begin{array}{l}0.482 \\
(138)\end{array}$ & $\begin{array}{l}0.429 \\
(123)\end{array}$ & & 3 & $\begin{array}{l}0.350 \\
(100)\end{array}$ & $\begin{array}{l}0.316 \\
(90.3)\end{array}$ & $\begin{array}{l}0.419 \\
(119.7)\end{array}$ & $\begin{array}{l}0.327 \\
(93.42)\end{array}$ \\
\hline & 100 & \begin{tabular}{|l}
0. \\
350 \\
$(100)$ \\
\end{tabular} & $\begin{array}{l}0.375 \\
(107)\end{array}$ & $\begin{array}{l}0.419 \\
(120)\end{array}$ & $\begin{array}{l}0.351 \\
(100.3)\end{array}$ & & 5 & $\begin{array}{l}0.350 \\
(100)\end{array}$ & $\begin{array}{l}0.313 \\
(89.42)\end{array}$ & $\begin{array}{l}0.375 \\
(107)\end{array}$ & $\begin{array}{l}0.308 \\
(88)\end{array}$ \\
\hline
\end{tabular}

Table 11. Photosynthetic efficiency (in term of $\mathrm{F}_{\mathrm{v}} / \mathrm{F}_{\mathrm{m}}$ ) of PS II of Anabaena grown under different concentrations of Monocrotophos and Endosulfan in laboratory condition.

\section{Conclusion}

The insecticide Monocrotophos and Endosulfan affected photosynthetic function which may have inhibited the growth of both the cyanobacteria by affecting the production of photosynthetic pigments in the antenna complex, electron transfer, and photosynthetic efficiency of PS-II. Both the cyanobacteria responded differently to both the pesticides with time and concentration dependent manner. Endosulfan has more inhibitory effect than Monocrotophos. Tolerance capacity of Nostoc sp. is more than Anabaena sp.. Our data indicate that use of Endosulfun may pose a risk to diazotropic cyanobacterium, and consequently to the nitrogen economy of the soil. It is currently understood from the extensive studies conducted so far on impacts of many pollutants on cyanobacteria and microalgae that evaluation with 
a wide taxonomic range in different ecosystem is necessary to arrive at a generalization on the nontarget effects of pollutant (Ramakrishnan et al., 2010) However, the effect of pesticides on the population of nitrogen-fixing cyanobacteria in rice fields also depends on pesticide concentrations, moreover, toxicity is affected not only by the types of pesticide, but also by the taxonomic groups and species. Since Endosulfan has more deleterious effect on natural engineer of the rice field (BGA) it's use be limited to maintain the stability of paddy ecosystem.

\section{Author details}

Binata Nayak and Shantanu Bhattacharyya

School of Life Sciences, Sambalpur University Jyoti Vihar, Burla, Odisha, India

Jayanta K. Sahu

Trust Fund College, Bargarh, Odisha India

\section{Acknowledgement}

Authors are thankful to HOD school of life Sciences, Sambalpur University for giving all types of facilities.

\section{References}

Agrochemical service,(2000): World Mackenize Consultants Limited. Edinborg, UK

Anand, N. and Subramanian, T.D. (1997): Effect of certain pesticides on the physiology of Nostoc calcicola. Phykos, 36: 15-20.

Battah, M.G; Shabana, E.F; Kobbia, I.A. and Eladel, H.M. (2001): Differential effects of thiobencarb toxicity on the growth and photosynthesis of Anabaena variabilis with changes in phosphate level. Ecotoxicol. Environ. Saf., 49: 235-239.

Behera, L.M. and Choudhury, N.K. (1997): Changes in chlorophyll fluorescence characteristics of chloroplasts from intact pumpkin cotyledous, caused by organ excision and kinetin treatment. Photosynthetica, 34: 161-168.

Behera, R.K. and Choudhury, N.K. (2001): Photosynthetic characteristics of chloroplasts of primary wheat leaves grown under different irradiances. Photosynthetica, 39: 11-15.

Behera, R.K; Mishra, P.C. and Choudhury, N.K. (2002): High irradiance and water stress induce alterations in pigment composition and chloroplast activities of primary wheat leaves. J. Plant Physiol., 159: 967-973.

Bhattacharyya S., Nayak B, Choudhury N.K. (2011): Response of Diazotropic cyanobacterium Nostoc carneum under pesticide and UV-B stress. Chemosphere 84:131-135

Bjorn,L.O., Papageorgiou,G. C.,Balnkenship, R. E. and Govindjee (2009): A view Point Why Chl $a$ ? photosynth Res. 99,85-98

Campbell, D; Vaughan, H; Adrian, K.C; Petter, G. and Gunnal, O. (1998): Chlorophyll fluorescence analysis of cyanobacterial photosynthesis and acclimation. Microbiol. Mol. Biol. Rev., 62: 667-683. 
Carvalho F P. (2006):. Agriculture, Pesticides, Food Security, and Food Safety, Encironmental science and policy, Elsevier,9:685-692.

Carvalho, F.P., Fowler, S.W., Villeneuve, J.-P., Horvat, M., (1997): Pesticide residues in the marine environment and analytical quality assurance of the results. In: Proceedings of an International FAO/IAEA Symposium on the Environmental Behaviour of Crop Protection Chemicals. IAEA, Vienna, pp. 35-57.

Chen, Z; Juneau, P. and Qia, B. (2007): Effect of three pesticides on the growth, photosynthesis and phtoinhibition of the edible cyanobacterium Nostoc (Ge-Xian-Mi). Aqu. Toxicol., 81: 256-265

Choudhury, N.K. and Choe, H.T. (1996): Photoprotective effect of kinetin on pigment content and photochemical activities of wheat chloroplasts aging in vitro. Biol. Plant., 38: 61-69.

Das, M.K. and Adhikary, S.P. (1996): Toxicity of three pesticides on several rice field cyanobacteria. Trop. Agric. (Trinidad), 73: 155-157.

Demming-Adams, B. Bjorkman, O (1987): Comparison of the effect of excessive light on chlorophyll fluorescence $(77 \mathrm{k})$ and photon yield of $\mathrm{O}_{2}$ evolution in levels of higher plants. Planta., 171: 171-184.

Deo, P.M. and Biswal, B. (1998): Water stress induced alterations in chloroplast activity and nitrogen metabolism during development of clusterbean cotyledons in low light intensity. In: Garab G. (Ed.), Photosynthesis: Mechanism and Effects, Vol.IV, Kluwer Academic Publishers, Dordrecht, Netherland, pp.2541-2544.

Falk, S. and Samuelsson, G. (1992): Recovery of photosynthesis and photosystem II fluorescence in Chlamydomonas reinhardtii after exposure to three levels of high light. Physiol. Plant., 85: 6168.

Fay,P., Stewart, W.D. P., Walsby, A. E., Fogg, G.E (1968): Is The Heterocyst Is The Site Of Nitrogen Fixation In Blue Green Algae? Nature 220, 810-812.

Fay P. (1983): The Blue greens (Cyanophyta-Cyanobacteria) First Published in Great Britain,pp. $1-88$

Fernández-Valiente, E.A., U.A. Quesada, F.Leganés and R. Careres, (2000). Contribution of N Fixing Cyanobacteria to Rice Production: Availability of Nitrogen from N-Labelled Cyanobacteria and Ammonium Sulphate to Rice.Plant Soil, 211: 107 - 112.

Goyal, D; Roychoudhury, P. and Kaushik, B.D. (1994): Effect of two new herbicides on the growth and nitrogen fixation in Anabaena and Tolypothisx. Acta Bot. Indica, 19: 25-28.

Gruszescki, W.I; Veeranjaneyulu, K; Zelent, B. and Leblane, R.M. (1991): Energy transfer process during senescence: Fluorescence and phtoacoustic studies of intact pea leaves. Biochim. Biophys. Acta, 1056: 173-180.

Hammouda, O. (1999): Response of the paddy field cyanobacterium Anabaena doliolum to carbofuran. Ecotoxicol. Environ. Saf., 44: 215-219.

Hideg, E. and Vass, I. (1996). UV-B induced free radical production in plant leaves and isolated thylakoid membranes. Plant Sci., 115: 251-260.

Jordan, B.R. (1996): The effects of ultraviolet-B radiation on plants: A molecular perspective. Adv. Biol. Res., 22: 97-162.

Kapoor, K. and Arrora, L. (1998): Ecophysiological observations on the influence of agrochemicals on growth and metabolism of Anabaena doliolum Bhardwaja. Ecol. Env. Cons., 4: 13-17. 
Kapoor, K. and Arrora, L. (2000a): Comparative studies on the effect of herbicides on nitrogen fixing cyanobacteria Cylindrospermum majukutz. Indian J. Env. Sci., 4: 89-96.

Kapoor, K. and Arrora, L. (2000b): Influence of some pesticides on cyanobacterium in vitro conditons. Indian J. Env. Ecoplanning, 3: 219-226.

Kaur, M.S.D. and Ahluwalia, A.S. (1997): Response of diazotrophic cyanobacteria to Butachlor. Phykos, 36: 93-101.

Kim, J.D. and Lee C.G. (2006): Differential response of two freshwater cyanobacteria, Anabaena variabilis and Nostoc commume to sulfonylurea herbicide bensulfuron-methyl. J. Micorbiol. Biotechnol., 16: 52-56.

Krause, G.H. (1988): Photoinhibition of photosynthesis - An evaluation of damaging and protective mechanisms. Physiol. Plant, 74: 566-574.

Krause, G.H. and Weis, E. (1991): Chlorophyll fluorescence and photosynthesis: The basics. Annu. Rev. Plant Physiol, Plant Mol. Biol., 42: 313-349.

Krieger, A; Moyo, I. and Weis, E. (1992): Energy dependent quenching of chlorophyll a fluorescence: Effect of $\mathrm{pH}$ on stationary fluorescence and picosecond relaxation kinetics in thylakoid membranes and PS II preparation. Biochim. Biophys. Acta, 1102: 167-176.

Kumar, A. and Kumar, H.D. (1998): Nitrogen fixation by blue-green algae. In: S.P. Sen (Ed.), Proceeding of Plant Physiological Research, $1^{\text {st }}$ International Congress of Plant Physiology, Society for Plant Physiology and Biochemistry, New Delhi, India, pp.85-103.

Kumar S, Habib K, Fatma T.(2008): Endosulfun induced biochemical changes in nitrogen-fixing cyanobacteria. The Science of the Total Environment,(ELSEVIER). 403:130-138.

Kumar, NJ.I., Bora, A., Amb, M K., Kumar, R N. (2011) . An evaluation of esticide Stress Induces Proteins in Three Cyanobacterial Species - Anabaena fertilissima, Aulosira fertilissima and Westillopsis prolifica Using SDS-PAGE. Advances in Environmental Biology 5(4): 739-745.

Lal, S. and Saxena, D.M. (1980): Cytological and biochemical effects of pesticides on microorganisms. Residue Rev., 73: 49-86.

Long, S.P. and Humphries, S. (1994): Photoinhibition of photosynthesis in nature. Annu. Rev. Plant Physiol. Plant Mol. Biol., 45: 633-662.

Mackinney, G. (1941): Absorption of light by chlorophyll solution. J. Biol. Chem., 140: 315-322.

Marsac, N.T.D. and Houmard, J. (1993): Adaptation of cyanobacteria to environmental stimuli: New step towards molecular mechanism. FEMS Microbiol. Rev., 104: 119-190.

Megharaj M., Venkateswarlu K., Naidu R. (2011): Effects of carbaryl and 1-Napthol on soil Population of Cyanobacteria and Microalgae and select cultures of diazotropic cyanobacteria Bull Environ Contam Toxicol 87:324-329.

Mishra U., Pabbi S. (2004): Cyanobacteria: a potential biofertilizer for rice. Resonance, 6-10.

Moreland, D.E. (1980): Mechanism of action of herbicides. Annu. Rev. Plant Physiol., 31: 597638.

Osmond, C.B. (1981): Photorespiration and Photoinhibition. Biochim. Biophys. Acta, 639: 77-98.

Panda, D; Rao, D.N; Sharma, S.G; Strasser, R.J. and Sarkar, R.K. (2006): Submergence effects on rice genotypes during seedling stage: Probing of submergence driven changes of phtosystem 2 by chlorophyll a fluorescence induction O-J-I-P transients. Phtosynthetica, 44: 1-7. 
Panda, M. (1999): Growth response of blue-green algae to paper mill waste water: Its possible role in pollution abatement, Ph.D. Thesis, Sambalpur University, Sambalpur, India.

Panda, S. and Biswal, U.C. (1989): Aging induced changes in thylakoid membrane organization and photoinhibition of pigments. Photosynthetica, 23: 507-516.

Panda, S. and Biswal, U.C. (1990): Effect of magnesium and calcium ions on photoinduced lipid peroxidation and thylakoid breakdown of cell-free chloroplast. Indian J. Biochim. Biophys., 27: 159-163.

Papageorgiou, G. (1975): Chlorophyll fluorescence: An intrinsic probe of photosynthesis. In: Govindjee (Ed.), Bioenergetics of Photosynthesis, Academic Press, New York, pp.319-371.

Peschek, G.A., Obinger, C., Sherman, D.M., Sherman, L.A (1994): Immunocytochemical localization of the cytochrome-c xidase in a cyanobacterium, Synechococcus PCC7942 (Anacystis nidulans). Biochim. Biophys. Acta 1187,369-372.

Powles, S.B. (1984): Photoinhibition of photosynthesis induced by visible light. Annu. Rev. Plant Physiol., 35: 15-19

Ramakrishnan B, Megharaj M, Venkateswarlu K. Naidu R. Scthunathan N (2010): The impact of Environmental pollutants on microalgae and cyanobacteria. Crit. Rev Environ Sci Technol 40:699-821.

Rath, B. and Adhikary, S.P. (1994): Relative tolerance of several nitrogen fixing cyanobacteria to commercial grade furadan. Ind. J. Expt. Biol., 32: 213-215.

Rippka, R; Deruelles, J; Waterbuy, J.B; Herdman, M. and Stanier, R.Y. (1979): Genetic assignments, strain histories and properties of pure cultures of cyanobacteria. J. Gen. Microbiol., 111: 1-61.

Rodrigues, V; Bhandari, R; Khurana, J.P. and Sharma, P.K. (2007): Movement of chloroplasts in mesophyll cells of Garcinia indica in response to UV-B radiation. Current Science, 92: 16101613.

Shikha and Singh D.P. (2004): Influence of glyphosphate on photosynthetic properties of wild type and mutant strains of cyanobacterium Anabaena doliolum. Current Science, 86: 571-576.

Swain, N.K; Choudhury, N.K; Raval, M.K. and Biswal, U.C. (1990): Differential changes in fluorescence characteristics of photosystem II rich grana fraction during ageing in light and dark. Photosynthetica, 24: 135-142.

Xia, J. (2005): Response of growth, photosynthesis and photoinhibition of the edible cyanobacterium N. sphaeroids colonies to thiobencarb herbicide. Chemosphere, 59: 561-566.

Ying-Yu, H. and Hader, D.P. (2002): UV-B induced formation of ROS and oxidative damage of the cyanobacterium Anabaena sp.: Protective effects of ascorbic acid and $\mathrm{N}$-acetyl-C-cystein. J. Photochem. Photobiol., 66: 115-124. 